across the Northern States into Canada. Thence it crossed Hudson's Bay and Labrador, into Davis Strait. Altering its course to south of east it passed the southern point of Greenland on October 16, and two days later, in lat. $55^{\circ}$ N., long. $27^{n}$ W., it was joined by another disturbance, which seems to have formed about October 9 in $20^{\circ} \mathrm{N} ., 48^{\circ} \mathrm{W}$. The junction of the two storms was followed by a complete cessation of progressive movement for a week (October I9 to 25), and it was during this period was formed as a subsidiary the gale which suddenly arrived over our south-eastern counties upon the morning of October 24, completely upsetting the Meteorological Office forecasts of the previous night The author quoted several records from ships, which went to show that this secondary storm had not formed until nearly midnight; and that reports from outlying coast-stations would not have enabled successful forecasts to be issued before $3 \mathrm{a} . \mathrm{m}$. on the $24 \mathrm{th}$. The $8 \mathrm{a}$.m. observations for the Daily Weather Report show that with the exception of Hurst Castle the winds on the northern side of the Channel were moderate, but along the French coast heavy gales were blowing. Ships' records indicate that off Start Point a moderate easterly gale began at 6.20 a.m. By S a.m. a whole gale from S.E. was blowing

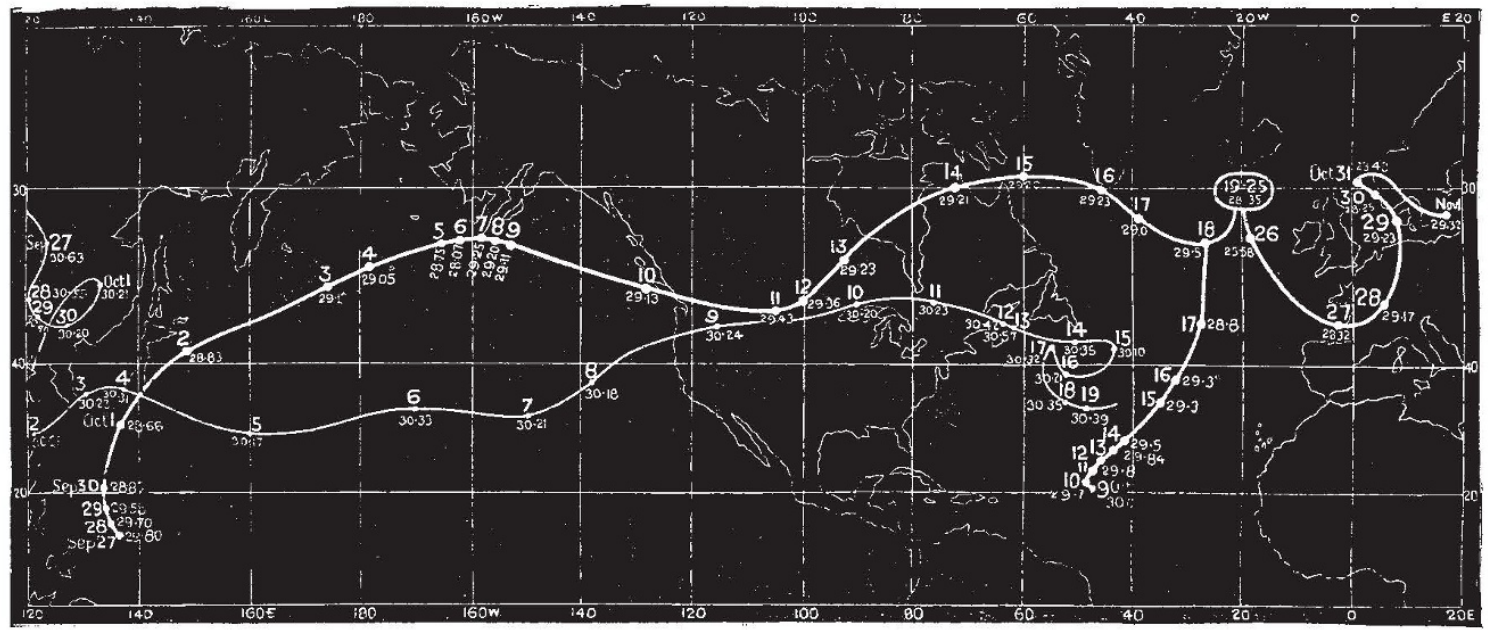

Tracks of the Typhoon and Anticyclone of September and October 1882 . The thick line shows the track of the typhoon, the thin line that of the anticyclone. The dates and the lowest and highest ascertained readings of the barometer for the day being given near the positions of the centres at Greenwich noon.

to south-west of Portland, while off the Start at 8.30 a.m. the wind veered to W.N.W. a strong gale. At 9 a.m. the wind off Portland veered to W. and blew with terrific violence. Further east, as far as the Downs, the wind had by noon changed to W. and S.W., and increased to a furious storm, with violent squalls and a terrible sea. As this gale passed away the primary moved into the Bay of Biscay and entered France on the 27th. As in Japan and America, its advance was marked by violent gales and destructive floods over a very extensive area-from Algeria northwards. The damage caused by the floods in

\section{THE NIVAL FLORA OF SWITZERLAND}

I $N$ the spring of 1883 (the last year of his life), the eminent Swiss naturalist, Prof. Oswald Heer, having finished his "Flora fossilis Arctica," resumed a work with which he had been long occupied before-viz. the preparation of a Nival Flora of Switzerland, in which he proposed to give an account of all the plants found above 8000 feet in that country, and a comparison of these with the Nival flora of other countries. This work, based on very abundant material, was nearly completed before the author's lamented death; - he anticipated being able to finish it in about eight days more had health allowed. The work has now been published in full (as he left it) in the Nouveaux Mémoires de la Société Helvétique des Sciences Naturelles (vol. xxix. part I). The summary of results of this research, which were communicated at a gathering of Swiss naturalists in Zurich, we will here reproduce.

(I) We know at present in Switzerland 337 species of flowering plants which have been observed at from 8000 to 13,000 feet above the sea; 12 of these species have still been found above 12,000 feet.
England was serious, but trifling compared with the losses in Southern and Central Europe, the destruction being enormous. This typhoon was the principal contributor in making October, I 882, by far the worst within living memory. With this final effort it seemed to have expended its fury, and in crossing France and the Netherlands it gradually filled up. The last trace of the typhoon was in the Baltic on November I, when it quietly dispersed, after covering over I4,000 nautical miles in thirty-six days, the longest track hitherto followed day by day.
(2) All these species are found in the lowest division of the Nival region, 8000 to 8500 feet. Above 8500 feet there is no species which is peculiar to this height.

(3) One-tenth of the species of the Nival region consists of species of lowland flora, nine-tenths of mountain plants. Most of the latter belong to the Alpine region, and about a quarter of the species has its greatest distribution over 8000 feet. These are the Nival plants in the narrower sense. While the lowland plants and the plants of the hilly and sub-Alpine region disappear at about 9500 feet, the Nival plants, with a few Alpine species, are the last children of the flora.

(4) The mountain mass of Monte Rosa has the richest Nival flora; which here rises higher than in the Rhretian Alps, and in the latter higher than in the Glärnisch Alps.

(5) The majority of the species are distributed throughout the whole region of the Alps; only a small portion is found exclusively in the east from Orteler to the Gothard, or in the west from the Gothard to Savoy.

(6) About half of the plants of the Nival region come from the Arctic zone, and very probably came over Scandinavia to our region in the Glacial period, since Arctic Europe has the largest number (140) of species 
which our Nival flora has in common with the Arctic zone.

(7) This Arctic flora probably arose on the mountains of the Arctic zone, and stood in the same relation, in the Miocene period, to the flora of the Arctic lowland as the present Alpine flora to the flora of the Swiss lowland.

(8) The Miocene Arctic flora advanced to Europe in the Tertiary period, and the European Tertiary flora received from it the types which now characterise the temperate zone, viz. the pine-woods and foliage-trees with deciduous leaves. In course of time these dominated more and more over the tropical and sub-tropical forms, which were the original occupiers of these regions, and became the mother-plants of a portion of the present lowland flora.

(9) In the Glacial period the mountain plants of the Arctic zone descended into the lowland, and spread southwards with the glaciers. As in the Tertiary period the trees and bushes with deciduous foliage wandered southwards, so in the Glacial period did the mountain plants; and that this migration took place radially from the north is proved by the fact that not only in the snow region of our Alps nearly the half of the plant species consists of Arctic species, but also the American mountains, and on the other side the Altai, and even the Himalaya, have quite a number of such Arctic species, and have them in common with the Swiss Alps. We know that already in the Tertiary period, and also in the period of the Upper Cretaceous, a number of plants can be traced from Greenland on to Nebraska, in North America, and on the other hand to Bohemia, Moravia, and on to Southern Europe. Thus in the period of the Cretaceous formation, in the Tertiary, and in the present formation, we find the same phenomenon: that Europe with America has a number of species in common which were formerly indigenous in the Arctic zone, and therefore very probably went out from that as their original home. The same process is thus repeated in different ages; the plant-world of the high north has at all times exercised a great influence on the formation of the plant-covering of Europe.

(IO) The endemic flora of the Nival region arose in our Alps. A principal centre of its formation seems to have been the Monte Rosa chain, in which probably, even during the Glacial period, extensive mountain masses of ice and névié were liberated.

(II) This flora received at the beginning of the Quaternary period its present character, and spread on the moraines of the glaciers into the lowland and into the mountainous regions of the neighbouring countries.

(12) Its mother flora had probably its abode in the Tertiary mountain country of Switzerland.

\section{NOTES}

WE understand that the post of Assistant Director of the Royal Gardens, Kew, has been offered to Mr. D. Morris, M. A., F.G.S., the Director of Public Gardens and Plantations, Jamaica. The appointment is in the gift of the First Lord of the Treasury.

So much has been heard during the last few years of the services rendered to the science, industry, and commerce of the West Indies by the public gardens and Government plantations of Jamaica under the superintendence of $\mathrm{Mr}$. Morris, that it is with surprise and regret that we learn that the future efficiency of these institutions is seriously threatened. A Select Committee, it appears, was recently appointed, under a resolution of the Council of Jamaica, "to consider the means of diminishing the expenses of the Government," and, among other suggestions and recommendations, it proposed that the Government cinchona plantations should be sold, and that the public gardens at Kingston should be handed over to the local authorities of that town to be maintained by them, instead of, as heretofore, by the Government, under the Director of Public Gardens. Committees appointed under these circumstances are generally more anxious to justify their existence by making recommendations than careful to inquire where they would be always possible or desirable. The cinchona plantations, thus threatened with extinction, were founded in 1868 by Sir John Peter Grant, and now consist of 150 acres under cinchona, with smaller areas under jalap, tea, and nurseries for timber and shade trees. According to the "Handbook of Jamaica," they distributed in five years to private planters 1200 ounces of cinchona-seed, 1, 200,000 cinchona seedlings, 400,000 cinchona piants, besides large quantities of timber and shade trees for re-foresting purposes. The Kingston Gardens, which are to be taken from under Mr. Morris's control, are used as a depot for plants from the other establishments, and also as the centre of distribution of plants and seeds to all parts of Jamaica and of the West Indies; there is no doubt, therefore, that they fulfil important functions.

If there was a single department in the whole Government service on which West Indian economists should have refrained from laying their hands except by way of increasing its scope and efficiency, we should have thought Mr. Morris's department that one. For if the West Indian Islands are ever to emerge from the disastrous economical condition of the past thirty years, and regain their previous flourishing state, it will be by the labours of institutions such as the public gardens, and of men such as Mr. Morris. Their old staples are useless to them, for Europe can bry them cheaper in other markets, and they must find new ones, or plunge deeper into the mire of financial embarrassment and bankruptcy, public and private. This can only be done by experiments and careful observations which no one bui a public clepartment and skilled botanists can carry out. Happily the economic value of the gardens in Jamaica have been recognised by the highest authorities. The Royal Commissioners stated that the department was invaluable, and that it was in as good a state as the sums placed at Mr. Morris's disposal would allow. The Governor coincided in this testimony, and added that "Mr. Morris was untiring in his endeavours to induce persons to commence new industries calculated to develop the resources of the island, and to bring about a condition of prosperity which would go far to counterbalance the depression under which the sugar industry of Jamaica now labours." It may be hoped therefore, notwithstanding the report of the Committee on Government Economy, that the department may be permitted to pursue its " invaluable" work on the same lines and with undiminished means.

Mr. Samuel Bircir, D.C.L., LL.D., F.S.A., Keeper of the Egyptian and Oriental Antiquities in the British Museum, died, on the $27_{\text {th }}$ inst., in his seventy-second year. Dr. Birch had served in the British Museum for fifty years, during the last part of which he was in charge of the Egyptian and Assyrian antiquities, and it is with this department of Oriental scholarship that his name will ever be associated. His early writings of nearly fifty years ago dealt mainly with Chinese subjects, and one of his first cluties at the British Museum was to catalogue the large collection of Chinese coins, and throughout the greater part of his life he manifested his interest in Chinese subjects by various publications. He was twice despatched to Italy on archæological missions on behalf of the Government, and in I 860 founded the Society of Biblical Archæology. His works on all departments of Egyptology fill many volumes, and extend over more than forty years, and at the time of his death he had in the press one work, while another, a new dictionary of hieroglyphics, was nearly completed. 